\title{
Genetic Variability Studies for Agro-Morphological, Yield and Yield Attributing Traits in Rapeseed (Brassica Rapa L.)
}

\author{
Mayurakshee Mahanta* and PurnaKantaBarua \\ Department of Plant Breeding and Genetics, Assam Agricultural University, \\ Jorhat 781017, India \\ *Corresponding author
}

\section{A B S T R A C T}

\begin{tabular}{|l}
\hline Ke y w o r d s \\
Rapeseed, Pooled \\
ANOVA, Genetic \\
variability, \\
heritability, Genetic \\
advance
\end{tabular}

\section{Keywords}

Rapeseed, Pooled ANOVA, Genetic variability, heritability, Genetic advance

\section{Introduction}

Indian rapeseed Brassica rapa (syn. $B$. campestris $2 \mathrm{n}=20$, AA) that includes the ecotypes Brown sarson, Yellow sarson and Toria belongs to the oilseed brassicas commonly known as rapeseed mustard is one of the most important group of edible oilbearing crops, from the Brassicaceae family. During 2017-18, rapeseed and mustard ranked third after soybean and groundnut, producing 80.41 lakh tonnes from an area of 60.06 lakh hactares with an average yield of $1339 \mathrm{~kg} / \mathrm{ha}$ (Anon, 2018). In Assam, rapeseed is the most important oilseed crop and major area under oilseeds is occupied by Toria (Brassica rapa var Toria) as the crop fits well in the rainfed cropping systems of Assam because of its short duration and low water requirement (80$240 \mathrm{~mm}$ ). With an acreage of 3.17 lakh hectares, producing about 2.04 lakh tonnes giving an average yield of only $643 \mathrm{~kg} / \mathrm{ha}$, Assam accounts for only 4.63 percent and 2.48 percent of the total Indian acreage and production, respectively (Anon.2018; DRMR, 2017).

Genetic variability is of prime importance for 
planning an efficient breeding programme for the improvement of Brassica species. Adequate variability for economic traits must be present in the working germplasm for profitable exploitation for fulfilling most of the changing needs for developing improved crop varieties following recombination breeding and selection. Studies on intra and inter population variability in segregating populations is necessary for selection of better performing varieties which are agronomically superior in addition to giving higher yields (Kumar et al.2012). Presence of large amount of genetic variation was reported by previous workers for seed yield and related traits in Indian rapeseed (Singh,1986; Barua, 1992; Singh and Kumar, 2007; Misra, 2012; Sikarwar, 2017). Agronomically desirable characters are found in Toria and Yellow Sarson forms of rapeseed. Toria is characterized by hollow and weak stem, shallow roots, low biological yield but high harvest index and short duration, while Yellow sarson, shows erect growth habit, deeper roots, solid stems, high biological yield but low harvest index. Oil content of yellow sarson is generally higher due to thin seed coat. Crosses between Toria and Yellow sarson were made to combine the desirable characters and performance of such inter varietal crosses are evaluated in the present investigation, in segregating generations including back crosses.

\section{Materials and Methods}

\section{Plant material and field experimentation}

The present experiment was conducted at the Instructional Cum Research Farm of Assam Agricultural University, Jorhat, during the rabi seasons of 2016-17 and 2017-18 (geographical coordinates: $26^{\circ} 57^{\prime} \mathrm{N}$ latitude and $94^{\circ} 12^{\prime} \mathrm{E}$ longitude and altitude of $86.6 \mathrm{~m}$ above the mean sea level) using randomized block design (RBD) with three replications. The experimental material selected for the work during 2016-17 comprised of four varieties, four F1, two F2, and eight back cross populations, as presented in Table 1.

The experiment was sown on $2^{\text {nd }}$ November, 2016. Each plot contained 3 rows measuring 3 $\mathrm{m}$ in length. Row to row spacing was $30 \mathrm{~cm}$ and spacing between plants was adjusted to about $10 \mathrm{~cm}$ by thinning at seedling stage. Well decomposed cow dung manure @ 2t/ha along with N: P2O5:K2O @ 60:40:40 kg/ha in the form of urea, single superphosphate and muriate of potash, respectively were applied. Borax was applied @ 10 kg/ha. Manual weeding and thinning were done four times in each experiment as per requirement. Irrigation was done manually at pre-sowing, active vegetative, flowering and pod filling stages. Necessary plant protection measures were taken to control pests and diseases.

The same populations were raised during 2017-18, the segregating populations being advanced by one generation. The experiment was sown on $9^{\text {th }}$ November, 2017 with the same design and plot size and similar agronomic practices.

\section{Trait evaluation}

Observations were recorded on 10 random plants in each plot for plant height $(\mathrm{cm})$, number of primary branches/plant, number of secondary branches/plant, main shoot length $(\mathrm{cm})$, number of siliquae on main shoot, seeds/siliqua, thousand seed weight $(\mathrm{g})$, maximum root length $(\mathrm{cm})$, biological yield per plant (g), seed yield per plant (g), harvest index (\%) stem texture (hollow/solid) and seed colour (using the Colour Chart of the Royal Horticultural Society, London). Days to flowering and maturity were observed on plot basis. Observations on yield and various yield attributing parameters were recorded by using standard procedures. 


\section{Data analysis}

The plot mean data were subjected to analysis of variance for each character following standard statistical procedure in the fixed model. Genotypic means were compared by computing least significant difference (Gomez and Gomez, 1984) in the experiment conducted during 2016-17 and 2017-18.

Genetic parameters were estimated for each character from the pooled ANOVA of 201617 and 2017-18 experiments. Genotypic variances $\left(\sigma^{2} \mathrm{~g}\right)$, phenotypic variance $\left(\sigma^{2} \mathrm{p}\right)$ and environmental variance $\left(\sigma^{2} \mathrm{e}\right)$ were computed following Sharma (1988) in fixed model. Genotypic coefficient of variation (GCV) and phenotypic coefficient of variation (PCV) were estimated from these variances in terms of standard deviation as percentage of the grand mean. Heritability $\left(h^{2}\right)$ in broad sense and the expected genetic advance at 5\% selection intensity were calculated following Allard (1960). Genetic advance was then expressed as percentage of the grand mean.

\section{Results and Discussion}

\section{Assessment of genetic variability}

Parameters of genetic variability worked out from the pooled analysis of variance of 2 experiments carried out in 2016-17 and 201718 crop seasons revealed significant genotypic differences for all the 13 characters recorded (Table 2). Genotypes x environment interactions were also significant for all the characters, indicating the sensitivity of the genotypes to environmental changes. Thus, genotypes performing well in one environment may not perform equally in other environments. Evaluation of mean performance of different populations indicated that out of the 18 populations studied, JT 1510-1 (YSH x TS 38), JT 15-9 (YSH 401 x Jeuti) and JT 15-1 [(Jeuti x YSH 401) x Jeuti)] were the 3 best populations for high seed yield and various yield attributing characters (Table 4. and 5.). The segregating generations of backcrosses involving toria and yellow sarson parents, had solid stem, while the segregating generations of direct crosses had both solid and hollow stems. The shades of seed colour in the crosses involving toria and yellow sarson were mostly lighter in colour than toria indicating that recombination among the genes for seed colour has taken place (Table 1.).

The extent of genetic variability could be best compared between different characters from the estimate of genotypic and phenotypic coefficients of variation (Burton, 1952). High GCV and PCV were observed for number of secondary branches/plants, harvest index, seed yield/plant and biological yield/plant; except days to maturity the rest of the characters showed moderate GCV and PCV (Table 3.). Even days to maturity ranged from 90 to 120 days. Thus, there was scope for improvement of those characters through selective breeding. High GCV was reported by Barman (1994) for secondary branches/ plant, and seed yield/plant in 33 genotypes of rapeseed. Salam et al., (2017) observed high GCV and PCV for number of branches/plant and harvest index and moderate GCV and PCV for plant height $(\mathrm{cm})$, siliqua length $(\mathrm{cm})$, number of siliquae/plant and seed yield/plant. High PCV and GCV were observed for number of secondary branches/plants followed by seed yield/plant, by Sikarwar et al., in yellow sarson (2017).

Heritability in broad sense, worked out from the pooled analysis was high for days to $50 \%$ flowering, days to maturity, number of secondary branches/plant, plant height, main shoot length, siliquae on main shoot, 1000 seed weight, seed yield/plant, biological yield/plant and harvest index and moderate for number of primary branches, maximum root length and seeds/siliqua. 
Table.1 Experimental rapeseed populations evaluated during Rabi 2016-17 and 2017-18 with the respective stem texture and seed colour

\begin{tabular}{|c|c|c|c|c|c|}
\hline SN & Population & Pedigree & Source & $\begin{array}{l}\text { Stem } \\
\text { texture }\end{array}$ & Seed colour \\
\hline 1. & Jeuti & M 27 x B 9 & Dept. of PBG, AAU & Solid & Greyed orange (166) \\
\hline 2. & TS 38 & Recurrent selection in M 27 & RARS, AAU, Shillongoni, Nagaon & Solid & Greyed orange (178) \\
\hline 3. & YSH 401 & & CCSHAU, Hisar & Solid & Greyed orange (176) \\
\hline 4. & $\begin{array}{l}\text { NRCYS } \\
05-03\end{array}$ & & DRMR, Bharatpur & Solid & Greyed orange (165) \\
\hline 5. & JT 15-1 & (Jeuti x YSH 401) x Jeuti & Dept. of PBG, AAU & Solid & Greyed orange (166) \\
\hline 6. & JT $15-2$ & (Jeuti x YSH 401) x YSH 401 & Dept. of PBG, AAU & Solid & Greyed orange(166) \\
\hline 7. & JT 15-3 & (NRCYS 05-03 X Jeuti) x Jeuti & Dept. of PBG, AAU & Solid & Greyed orange(176) \\
\hline 8. & JT 15-4 & $\begin{array}{l}\text { (NRCYS 05-03 X TS 38) x } \\
\text { NRCYS 05-03 }\end{array}$ & Dept. of PBG, AAU & Solid & Greyed orange (175) \\
\hline 9. & JT 15-1-1 & (YSH 401 x Jeuti) x Jeuti & Dept. of PBG, AAU & Hollow & Greyed orange (175) \\
\hline 10. & JT $15-5$ & (YSH $401 \times$ TS 38) x TS38 & Dept. of PBG, AAU & Hollow & Greyed orange (175) \\
\hline 11. & JT 15-1-2 & (YSH 401 x Jeuti) x YSH 401 & Dept. of PBG, AAU & Solid & Greyed orange (166) \\
\hline 12. & JT 15-5-1 & (YSH 401 x TS 38) x YSH 401 & Dept. of PBG, AAU & Solid & Greyed orange(166) \\
\hline 13. & JT 15-6 & Jeuti x YSH 401 & Dept. of PBG, AAU & Hollow & Greyed red(178) \\
\hline 14. & JT 15-7 & NRCYS 05-03 x Jeuti & Dept. of PBG, AAU & Hollow & Greyed orange (166) \\
\hline 15. & JT $15-8$ & NRCYS 05-03 x TS 38 & Dept. of PBG, AAU & Hollow & Greyed orange (177) \\
\hline 16. & JT 15-9 & YSH 401 x Jeuti & Dept. of PBG, AAU & Hollow & Brown $(200)$ \\
\hline 17. & JT 15-10 & YSH $401 \times$ TS 38 & Dept. of PBG, AAU & Solid & Yellow orange (20) \\
\hline 18. & JT $15-10-1$ & YSH $401 \times$ TS 38 & Dept. of PBG, AAU & Solid & Yellow orange (20) \\
\hline
\end{tabular}


Table.2 Pooled analysis of variance (mean square) for seed yield and related traits in rapeseed

\begin{tabular}{|c|c|c|c|c|c|c|c|c|c|c|c|c|c|c|}
\hline $\begin{array}{c}\text { Sources of } \\
\text { variation }\end{array}$ & df & DF & DM & PH & PB & SB & MSL & SMS & SSQ & MRL & TSW & BYP & SYP & $\begin{array}{c}\text { HI } \\
(\%)\end{array}$ \\
\hline & 4 & $\begin{array}{c}5.86 \\
*\end{array}$ & $\begin{array}{c}12.58 \\
*\end{array}$ & $\begin{array}{c}84.42 \\
* *\end{array}$ & 0.52 & 0.42 & ** & $\begin{array}{c}34.00 \\
*\end{array}$ & $\begin{array}{c}12.98 \\
* *\end{array}$ & 2.13 & $\begin{array}{l}0.11 \\
*\end{array}$ & 7.30 & $\begin{array}{l}1.19 \\
*\end{array}$ & $\begin{array}{c}58.25 \\
*\end{array}$ \\
\hline Ge & 17 & $\begin{array}{c}76.60 \\
* *\end{array}$ & $\begin{array}{c}351.51 \\
* *\end{array}$ & $\begin{array}{c}529.95 \\
* *\end{array}$ & $\begin{array}{c}8.40 \\
* *\end{array}$ & $\begin{array}{c}30.64 \\
* *\end{array}$ & $\begin{array}{c}188.49 \\
* *\end{array}$ & $\begin{array}{c}325.78 \\
* *\end{array}$ & $\begin{array}{c}65.69 \\
* *\end{array}$ & $\begin{array}{c}18.08 \\
* *\end{array}$ & $\begin{array}{c}0.53 \\
* *\end{array}$ & $\begin{array}{c}62.59 \\
* *\end{array}$ & $\begin{array}{c}12.95 \\
* *\end{array}$ & $\begin{array}{c}346.37 \\
* *\end{array}$ \\
\hline Pooled err & 68 & 1.68 & 4.66 & 20.33 & 0.71 & 1.02 & 9.11 & 12.01 & 2.38 & 1.63 & 0.03 & 2.99 & 0.81 & 24.85 \\
\hline CV\% & & 1.86 & 1.14 & 2.43 & 5.64 & 9.00 & 3.26 & 3.82 & 5.55 & 3.48 & 3.02 & 4.53 & 3.95 & 6.80 \\
\hline
\end{tabular}

* Significant at $\mathrm{P}=0.05$ and ** Significant at $\mathrm{P}=0.01, \mathrm{DF}=$ Days to $50 \%$ flowering, $\mathrm{DM}=$ Days to maturity, $\mathrm{PH}=\mathrm{Plant}$ height, $\mathrm{PB}=\mathrm{No}$. of primary branches, $\mathrm{SB}=$ No. of secondary branches, $\mathrm{MSL}=$ Main shoot length, $\mathrm{SMS}=$ Silquae on main shoot, $\mathrm{SSQ}=$ Seeds per siliqua, $\mathrm{MRL}=\mathrm{Maximum}$ root length, $\mathrm{TSW}=$ Thousand seed weight, BYP = Biological yield/plant, SYP = Seed yield/plant, HI = Harvest index

Table.3 Estimates of genetic parameters for various characters in rapeseed

\begin{tabular}{|c|c|c|c|c|c|}
\hline Character & Range & GCV (\%) & PCV (\%) & Heritability (\%) & GA (\%) \\
\hline Days to $50 \%$ flowering & $33.33-49.33$ & 12.44 & 12.86 & 93.66 & 24.80 \\
\hline Days to maturity & $89.66-120.5$ & 9.87 & 10.07 & 96.12 & 19.94 \\
\hline Plant height (cm) & $92.29-122.86$ & 12.18 & 12.89 & 89.31 & 23.71 \\
\hline Main shoot length (cm) & $40.68-61.47$ & 14.50 & 15.56 & 86.78 & 27.82 \\
\hline No. of primary branches/plant & $6.50-10.5$ & 18.56 & 20.97 & 78.32 & 33.83 \\
\hline No. of secondary branches/plant & $1.00-9.16$ & 48.40 & 50.85 & 90.60 & 94.91 \\
\hline No. of siliquae on main shoot & $36.33-60.83$ & 19.51 & 20.60 & 89.70 & 38.07 \\
\hline No. of seeds per siliqua & $12.50-16.33$ & 18.56 & 20.97 & 78.32 & 33.84 \\
\hline Maximum root length $(\mathrm{cm})$ & $19.31-24.71$ & 11.06 & 12.60 & 77.07 & 20.01 \\
\hline 1000 seed weight $(\mathrm{g})$ & $2.60-3.90$ & 12.18 & 13.26 & 84.40 & 23.05 \\
\hline Seed yield per plant (g) & $7.61-12.93$ & 20.70 & 21.80 & 90.17 & 40.49 \\
\hline Biological yield per plant (g) & $17.35-28.92$ & 20.30 & 21.76 & 87.02 & 39.01 \\
\hline Harvest index (\%) & $31.35-57.91$ & 22.31 & 24.76 & 81.18 & 41.40 \\
\hline
\end{tabular}


Table.4 Mean performance of different populations for developmental traits related to seed yield in rapeseed

\begin{tabular}{|l|c|c|c|c|c|c|}
\hline Population & DF & DM & PH & MSL & SMS & MRL \\
\hline JT 15-1 & 39.16 & 110.16 & 121.54 & 52.13 & 54.00 & 21.10 \\
\hline JT 15-2 & 39.00 & 105.16 & 117.54 & 56.43 & 56.16 & 19.76 \\
\hline JT 15-3 & 37.50 & 111.50 & 118.62 & 58.50 & 58.66 & 21.11 \\
\hline JT 15-4 & 42.50 & 111.50 & 108.98 & 51.15 & 49.16 & 20.61 \\
\hline JT 15-1-1 & 40.33 & 109.83 & 97.49 & 51.10 & 56.33 & 22.15 \\
\hline JT 15-5 & 38.50 & 109.33 & 99.75 & 51.45 & 53.50 & 19.28 \\
\hline JT 15-1-2 & 39.66 & 109.83 & 105.40 & 51.81 & 53.16 & 20.00 \\
\hline JT 15-5-1 & 39.83 & 109.33 & 107.76 & 55.70 & 55.66 & 23.85 \\
\hline JT 15-6 & 39.00 & 112.66 & 96.02 & 51.33 & 54.66 & 20.85 \\
\hline JT 15-7 & 39.66 & 109.50 & 105.66 & 58.40 & 57.66 & 19.16 \\
\hline JT 15-8 & 40.50 & 113.83 & 105.69 & 57.80 & 55.00 & 19.54 \\
\hline JT 15-9 & 40.66 & 106.00 & 122.86 & 61.47 & 60.83 & 19.32 \\
\hline JT 15-10 & 43.00 & 111.16 & 117.76 & 58.98 & 60.83 & 20.91 \\
\hline JT 15-10-1 & 44.16 & 111.66 & 100.10 & 59.48 & 55.83 & 23.28 \\
\hline Jeuti & 33.33 & 89.66 & 92.29 & 42.93 & 36.33 & 20.32 \\
\hline TS 38 & 34.16 & 91.00 & 95.27 & 40.68 & 36.66 & 21.18 \\
\hline YSH 401 & 42.66 & 117.83 & 106.22 & 49.05 & 43.00 & 23.96 \\
\hline NRCYS 05-03 & 49.33 & 120.50 & 107.59 & 51.68 & 46.00 & 24.72 \\
\hline Mean & $40.16 \pm 0.53$ & $108.91 \pm 0.88$ & $107.03 \pm 1.84$ & $53.34 \pm 1.23$ & $52.42 \pm 1.42$ & $21.17 \pm 0.52$ \\
\hline CD (P=0.05) & 1.50 & 2.49 & 5.21 & 3.49 & 4.00 & 1.48 \\
\hline CD (P=0.01) & 2.25 & 3.21 & 6.69 & 5.23 & 6.00 & 2.21 \\
\hline D D & & & & \\
\hline
\end{tabular}

$\mathrm{DF}=$ Days to 50\% flowering, $\mathrm{DM}=$ Days to maturity, $\mathrm{PH}=$ Plant height, $\mathrm{MSL}=$ Main shoot length, $\mathrm{SMS}=$ Silquae on main shoot, $\mathrm{MRL}=\mathrm{Maximum}$ root length. 
Table.5 Mean performance of different populations for seed yield and component traits in rapeseed

\begin{tabular}{|c|c|c|c|c|c|c|c|}
\hline Populations & PB & SB & SSQ & TSW (g) & SYP (g) & BYP (g) & HI \\
\hline JT 15-1 & 10.50 & 8.83 & 18.16 & 3.38 & 11.94 & 22.06 & 54.8 \\
\hline JT 15-2 & 8.83 & 5.16 & 16.83 & 3.42 & 9.27 & 20.50 & 46.56 \\
\hline JT 15-3 & 8.83 & 7.16 & 16.33 & 3.34 & 7.61 & 22.12 & 36.06 \\
\hline JT 15-1-1 & 7.50 & 7.33 & 18.00 & 3.35 & 9.20 & 21.04 & 44.38 \\
\hline JT 15-5 & 9.16 & 7.33 & 13.16 & 3.40 & 9.60 & 18.83 & 51.60 \\
\hline JT 15-1-2 & 7.16 & 4.33 & 13.00 & 3.60 & 8.74 & 21.35 & 41.26 \\
\hline JT 15-6 & 8.50 & 8.00 & 14.00 & 3.44 & 9.40 & 19.86 & 48.58 \\
\hline JT 15-7 & 8.83 & 9.00 & 18.83 & 3.70 & 9.18 & 20.76 & 44.80 \\
\hline JT 15-8 & 8.33 & 6.83 & 12.50 & 3.08 & 11.50 & 26.58 & 46.00 \\
\hline JT 15-9 & 9.16 & 6.33 & 15.50 & 3.68 & 12.58 & 22.14 & 57.23 \\
\hline JT 15-10 & 9.16 & 6.83 & 16.00 & 3.90 & 8.40 & 25.02 & 33.83 \\
\hline JT 15-10-1 & 11.00 & 9.16 & 15.33 & 2.60 & 12.93 & 27.74 & 46.13 \\
\hline NRCYS 05-03 & 8.00 & 1.33 & 26.33 & 3.04 & 8.98 & 28.92 & 31.35 \\
\hline Mean & $8.62 \pm 0.34$ & $6.49 \pm 0.41$ & $16.02 \pm 0.63$ & $3.36 \pm 0.07$ & $9.8 \pm 0.28$ & $21.96 \pm 0.7$ & $46 \pm 2.04$ \\
\hline $\mathrm{CD}(\mathrm{P}=\mathbf{0 . 0 5})$ & 0.97 & 1.17 & 1.78 & 0.20 & 0.78 & 1.99 & 5.76 \\
\hline $\mathrm{CD}(\mathrm{P}=0.01)$ & 1.25 & 1.51 & 2.67 & 0.26 & 1.00 & 2.56 & 7.40 \\
\hline
\end{tabular}

$\mathrm{PB}=$ No. of primary branches, $\mathrm{SB}=$ No. of secondary branches, $\mathrm{SSQ}=$ Seeds per siliqua, $\mathrm{TSW}=$ Thousand seed weight, $\mathrm{BYP}=\mathrm{Biological}$ yield $/$ plant, $\mathrm{SYP}=$ Seed yield/plant, $\mathrm{HI}=$ Harvest index 
Joya et al., (2016) reported high heritability for yield related characters except 1000 seed weight in rapeseed whereas, Ara et al., (2013) reported high heritability for days to flowering, days to maturity and number of branches/plants. Consideration of heritability and genetic advance together is more effective for prediction of gain in selection than heritability alone. High heritability and high genetic advance are indicative of additive gene effects (Panse, 1957). High heritability coupled with high GCV and high genetic advance were observed for secondary branches, harvest index, seed yield/plant and biological yield/plant. High heritability coupled with high genetic advance was recorded for siliquae on main shoot. For these characters additive gene effects were probably more influential than non-additive gene effects. These estimates were in close agreement with Koch (2005) and Singh and Kumar (2007) in toria. High heritability with moderate genetic advance was observed for days to flowering, plant height and main shoot length. Moderate heritability coupled with high genetic advance was recorded for primary branches and number of seeds/ siliquae. Sikarwar (2017) reported high heritability with moderate genetic advance in case of length of siliqua and 1000 seed weight in yellow sarson whereas, Kumar et al., (2012) and Jahan et al., (2014) reported high heritability and moderate genetic advance for days to flowering. In the inheritance of all these characters non-additive gene effects could be more influential than additive gene effects.

JT 15-10-1, JT 15-9 and JT 15-1 were identified as high yielding populations with good performance for various characters in the present study. These lines can be further evaluated and promoted as potential varieties. Selection for Number of secondary branches per plant, harvest index, seed yield per plant and biological yield per plant (high GCV, $\mathrm{h}^{2} \mathrm{bs}$ and GA) would be fruitful. Backcross populations involving toria and yellow sarson can be used in future studies for introgression of useful genes for more oil content, selfcompatibility and yellow seeds.

\section{References}

Allard R. W. 1960. Principles of Plant Breeding. John Wiley and Sons. New York.

Anon. 2018. https// nfsm. gov.in/ ReadyReckoner/ Stat_OS2018.pdf.

Ara S., Afroz S., Noman M.S., Bhuiyan M. S. R. and Zia, M. I. K. 2013. Variability, correlation and path analysis in $\mathrm{F}_{2}$ progenies of inter-varietal crosses of Brassica rapa. J. Environ. Sci. \& Natural Resources., 6 (1): 217 - 220.

Barman B. 1994. Studies on intra and inter population variability in rapeseed (Brassica campestris L.). Unpublished M. Sc. Thesis, Assam Agricultural University, Jorhat.

Barua P. K. 1992. Genetic analysis of yield parameters in varietal hybrids of Indian rapeseed (Brassica campestris L.). Unpublished $\mathrm{Ph}$. D. Thesis, Assam Agricultural University, Jorhat.

Burton G.W. 1952. Quantitative inheritance of grasses. Proc. 6th. Inter. Genet., Cong. 1: 227-283.

DRMR. 2017. Ann. Rep. Directorate of Rapeseed-Mustard Research, ICAR, Bharatpur.

Gomez K.A. and Gomez A.A. 1984. Statistical procedure for agricultural research. John Wiley and Sons, New York.

Jahan N., Khan M.H., Ghosh S., Bhuiyan S.R and Hossain S. 2014. Variability and heritability analysis in F4 genotypes of Brassica rapaL. Bangladesh J. Agric. Res., 39 (2): 227-241.

Joya S.D., Shamsuddin A.K.M. and Nath 
U.K. 2016.Genetic variability and character association in rapeseed (Brassica NapusL.). Bangladesh J. of Plant Breed. and Genet., 29 (2):11-16.

Koch K. K. 2005. Genetic variation and selection response in toria under delayed sowing in rice fallow. Unpublished M. Sc. Thesis, Assam agricultural University, Jorhat.

Kumar H., Srivastava A., Vishwakarma M.K. and Lal J.P. 2012. Genetic Enhancement of Variability Through Induced Mutagenesis in Two Genotypes of Brassica napus L. Madras Agric. J., 99 (4-6): 228-231.

Misra A. K. 2012. Genetic variability and correlation studies on germplasm of yellow sarson (B. rapaL. var. yellow sarson) for seed yield and its component traits. Cruciferae Newsletter., 31: 46.

Panse V.G. 1957. Genetic of quantitative characters in relation to plant breeding. Indian J. Genet., 17: 318-329.

Salam J.L., Mehta N., Tomar, N.S., Saxena
R.R., Saxena R.R. and Sarawagi A.K. 2017. Genetic variability analysis of yield and its components in Brassica compestris var. toria. Electr. J. Plant Breed., 8 (1): 320-323.

Sharma J. R. 1988. Statistical and biometrical techniques in plant breeding. New Age International, New Delhi.

Sikarwar R.S., Satankar N., Kushwah M.K. and Singh A.K. 2017. Genetic Variability, Heritability and Genetic Advance Studies in Yellow Sarson (Brassica rapa var. Yellow Sarson). Intern. J. Agric. Innov. Res., 5 (5): 2319-1473.

Singh H. 1986. Genetic variability, heritability and drought index analysis in Brassica species. J. Oilseed Research., 3: 170-177.

Singh T. and Kumar R. 2007. Genetic variability and correlation analysis over different environments in toria (Brassica campestris L. var. toria). SKUAST J. of Research., 6 (1): 47- 53.

\section{How to cite this article:}

Mayurakshee Mahanta and PurnaKantaBarua. 2019. Genetic Variability Studies for AgroMorphological, Yield and Yield Attributing Traits in Rapeseed (Brassica Rapa L.). Int.J.Curr.Microbiol.App.Sci. 8(09): 927-935. doi: https://doi.org/10.20546/ijcmas.2019.809.109 